\title{
TREN MORTALITAS BERDASARKAN TINGKAT KECELAKAAN LALU LINTAS 5 TAHUN TERAHKIR DI KECAMATAN BULELENG
}

\author{
I Kadek Irianta Wijaya ${ }^{1}$, Putu Indra Christiawan ${ }^{2 *}$ \\ Prodi Pendidikan Geografi, Universitas Pendidikan Ganesha, Indonesia
}

\author{
A R T I C L E I N F O \\ Article history: \\ Received 19 Agustusl 2018 \\ Received in revised form \\ 6 November 2018 \\ Accepted 12 November \\ 2018 \\ Available online 30 \\ November 2018

\begin{tabular}{l}
\hline Kata Kunci: \\
Tren \\
Mortalitas \\
kecelakaan \\
lalu lintas. \\
Keywords: \\
Trends \\
Mortality \\
traffic \\
arridentc
\end{tabular}

\begin{abstract}
A B S T R A K
Penelitian ini bertujuan (1) Menganalisis sebaran spasial lokasi rawan kecelakaan lalu lintas yang terjadi selama kurun waktu tahun 2013-2017 di Kecamatan Buleleng (2) Mengidentifikasi faktor penyebab kecelakaan lalu lintas yang terjadi selama kurun waktu tahun 2013-2017 di Kecamatan Buleleng (3) Mengkaji tren mortalitas yang terjadi, dilihat dari tingkat kecelakaan lalu lintas selama kurun waktu tahun 2013-2017 di Kecamatan Buleleng. Rancangan yang digunakan dalam penelitian ini adalah penelitian deskriptif dengan metode pengumpulan data pencatatan dokumen yang selanjutnya dianalisis dengan menggunakan analisis deksriptif kualitatif. Hasil penelitian menunjukan bahwa (1) Sebaran lokasi rawan kecelakaan lalu lintas di Kecamatan Buleleng memiliki pola yang menyebar yaitu di Zona Inti Kota dengan 5 lokasi rawan kecelakaan, Zona Selaput Inti Kota dengan 3 lokasi rawan kecelakaan dan Zona Pinggiran Kota dengan 5 lokasi rawan kecelakaan (2) Faktor penyebab kecelakaan lalu lintas yang terjadi di Kecamatan Buleleng selama kurun waktu tahun 2013-2017 adalah faktor manusia dengan presentase $100 \%$ dari total 579 kasus
\end{abstract} kecelakaan lalu lintas (3) Tren mortalitas yang terjadi akibat kecelakaan lalu lintas selama kurun waktu tahun 2013-2017 di Kecamatan Buleleng mengalami fluktuasi, dibuktikan dengan peningkatan jumlah mortalitas terjadi pada tahun 2013 dengan total 21 korban jiwa, tahun 2015 dengan total 18 korban jiwa dan tahun 2017 dengan total 18 korban jiwa kemudian mengalami penurunan jumlah mortalitas pada tahun 2014 dengan total 14 korban jiwa dan tahun 2016 dengan total 15 korban jiwa.

\section{A B S T R A C T}

This research aims to (1) analyzes the spatial distribution locations prone to traffic accidents that occurred during the period of 2013 until 2017 in Buleleng Sub-District (2) to identify the causes of traffic accidents that occurred during the period of 2013 until 2017 in Buleleng Sub-District (3) examines trends occurring mortality, judging by the level of traffic accidents during the period 2013 until 2017 in Buleleng Sub-District. The design used in this research is descriptive method of recording data collecting further documents were analyzed using qualitative descriptive analysis. The results showed that (1) Distribution locations prone to traffic accidents in Buleleng Sub-District has a pattern that spreads are in the Core Zone of the City with 5 locations prone to accidents, Tunica Core Zone Cities with 3 locations prone to accidents and Suburban Zone with 5 locations prone to accidents (2) The factors causing a traffic accident that occurred in Buleleng Sub-District for the period of 2013 until 2017 is the human factor with a percentage of $100 \%$ of the total 579 cases of traffic accidents (3) Trends in mortality caused by traffic accidents during the period 2013 until 2017 in Buleleng SubDistrict is fluctuated, evidenced by the increase in the number of mortality occurred in 2013 with a total of 21 fatalities, in 2015 with a total of 18 fatalities and in 2017 with a total of 18 victims soul then decreased the amount of mortality in 2014 with a total of 14 fatalities and 2016 with a total of 15 fatalities.

Copyright (C) Universitas Pendidikan Ganesha. All rights reserved.

\footnotetext{
* Corresponding author.

E-mail addresses: irianta.w18@gmail.com (Penulis Pertama), indra.christiawan@undiksha.ac.id (Penulis Kedua)
} 



\section{Pendahuluan}

Lembaga Demografi Fakultas Ekonomi Universitas Indonesia (1981) mengungkapkan mortalitas atau kematian merupakan salah satu diantara tiga komponen demografi yang dapat mempengaruhi perubahan penduduk dan dua komponen demografi lainnya adalah fertilitas dan migrasi. Mortalitas sebagai salah satu komponen proses kependudukan tidak hanya berperan dalam mempengaruhi pertumbuhan penduduk, tetapi merupakan indikator yang menggambarkan tentang tinggi rendahnya tingkat kesehatan penduduk di suatu daerah (Razake, 1988). (Siswono, 2015) mendefinisikan kematian sebagai suatu peristiwa menghilangnya semua tanda-tanda kehidupan secara permanen, bisa terjadi setiap saat setelah kelahiran hidup.

Tinggi-rendahnya kematian yang terjadi di suatu daerah dipengaruhi oleh faktor penghambat kematian dan faktor pendukung kematian. Faktor penghambat kematian (anti mortalitas) antara lain: meningkatnya kesadaran penduduk akan pentingnya kesehatan, memperbanyak tenaga medis seperti dokter, fasilitas kesehatan yang memadai meningkatnya keadaan gizi penduduk, dan kemajuan di bidang kedokteran. Pada sisi lain faktor pendukung kematian (pro-mortalitas) antara lain: rendahnya kesadaran masyarakat akan pentingnya kesehatan, fasilitas kesehatan yang belum memadai, keadaan gizi penduduk yang rendah, terjadinya bencana alam, peperangan, wabah penyakit, dan kecelakaan lalu lintas (Annisak, H., 2009).

Menurut Jenderal Tito Karnavian selaku Kepala Kepolisian Indonesia menyatakan masalah lalu-lintas yang paling tinggi adalah kecelakaan di jalan, dengan jumlah korban kecelakaan lalu lintas sekitar 28 sampai 30 ribu jiwa per tahun (Kurniawati dalam Berita Tempo "Angka Kecelakaan Lalu Lintas Indonesia Termasuk Tinggi di ASEAN, 2017). Apa yang diberitakan oleh Tempo.Co selaras dengan hasil penelitian yang dilakukan oleh Sulistiyowati, N., \& Senewe (2014), tentang Pola Penyebab Kematian Usia Produktif (15-54 Tahun). Hasil penelitian menunjukkan, dari 12 kabupaten/kota di Indonesia yang menjadi lokasi penelitian dihadapkan dengan masalah triple burder diseases, di antaranya penyakit tidak menular yang mengalami peningkatan, seperti kecelakaan lalu lintas, cerebrovascular dan penyakit menular masih menjadi masalah seperti tuberkulosis, diare, serta meningkatnya penyakit menular baru, yaitu HIV dan AIDS.

Hasil yang sama ditunjukkan pada penelitian yang dilakukan oleh Djaja dkk (2016), tentang Gambaran Kecelakaan Lalu Lintas di Indonesia Tahun 2010-2014. Hasil penelitian menyatakan bahwa masalah kecelakaan lalu lintas di Indonesia saat ini sangat urgent, harus ditangani segera secara holistik dan komprehensif. Proporsi kematian yang tinggi akibat kecelakaan lalu lintas terjadi di beberapa provinsi dengan jumlah penduduk yang tinggi, serta keadaan lalu lintas yang padat, seperti di Jawa Barat, Jawa Tengah, Jawa Timur, DKI Jakarta, Sumatera Utara. Angka kejadian kecelakaan lalu lintas dan proporsi kematian tertinggi terjadi pada kelompok umur produktif (26 - 30 tahun).

Peristiwa kecelakaan lalu lintas yang terjadi di setiap daerah atau wilayah yang umumnya disebabkan oleh banyak faktor. Pada dasarnya disebabkan oleh kurang 
efektifnya gabungan dari faktor-faktor utama yaitu: pemakai jalan (manusia), lingkungan dan kendaraan. Menurut data Kepolisian, besarnya jumlah kecelakaan di Indonesia disebabkan oleh beberapa faktor, yaitu faktor manusia 61\%, faktor prasarana dan lingkungan 30\% dan faktor kendaraan 6\%. Faktor-faktor tersebut mengakibatkan jumlah kematian akibat kecelakaan lalu lintas menjadi tinggi (Kementerian Kesehatan Republik Indonesia, 2017).

Kabupaten Buleleng merupakan kabupaten terluas yang berada di Provinsi Bali. Jumlah penduduk Kabupaten Buleleng pada tahun 2013 mencapai 805,723 ribu jiwa. Jumlah tersebut mengalami peningkatan di tahun 2016 menjadi 806,449 ribu jiwa. Peningkatan jumlah penduduk di Kabupaten Buleleng diiringi dengan peningkatan kebutuhan akan kepemilikan kendaraan bermotor. Kabupaten Buleleng mengalami peningkatan dalam jumlah kendaraan bermotor pada empat tahun terakhir, yaitu dari tahun 2013 sampai tahun 2016. Tercatat pada tahun 2013 jumlah kendaraan bermotor di Kabupaten Buleleng sebanyak 216.552 unit dan mengalami peningkatan di tahun 2016 menjadi 381,916 unit (Badan Pusat Statistik, 2017). Hal ini menjadikan Kabupaten Buleleng dihadapkan dengan permasalahan lalu lintas diantaranya terindikasi meningkatnya angka kecelakaan lalu lintas.

Berdasarkan data Satuan Lalu Lintas Polres Buleleng tahun 2017, disebutkan bahwa telah terjadi peningkatan kasus kecelakaan lalu lintas dari 262 kasus di tahun 2015 menjadi 333 kasus di tahun 2016. Peningkatan jumlah kecelakaan lalu lintas kembali terjadi pada tahun 2016, seiring dengan peningkatan jumlah penduduk dan jumlah kendaraan bermotor yang berada di Kabupaten Buleleng. Secara umum peristiwa kecelakaan lalu lintas di Kabupaten Buleleng, dominasi terjadi di Kecamatan Buleleng. Mendominasi peristiwa kecelakaan lalu lintas di Kecamatan Buleleng dipandang wajar karena Kecamatan Buleleng merupakan wilayah urban di Kabupaten Buleleng. Kecamatan Buleleng sebagai wilayah urban tentu memiliki keadaan lalu lintas yang padat bila di bandingkan dengan kecamatan lain. Tingginya angka kecelakaan lalu lintas bisa menjadi salah satu faktor penyebab kematian, sama halnya dengan tingginya kasus kecelakaan lalu lintas di Kecamatan Buleleng.

Berdasarkan latar belakang di atas, maka adapun rumusan masalah dalam penelitian ini adalah (1) Bagaimana sebaran spasial lokasi rawan kecelakaan lalu lintas selama kurun waktu tahun 2013-2017 di Kecamatan Buleleng? (2) Apa faktor penyebab kecelakaan lalu lintas selama kurun waktu tahun 2013-2017di Kecamatan Buleleng? (3) Bagaimana tren mortalitas yang terjadi, dilihat dari tingkat kecelakaan lalu lintas selama kurun waktu tahun 2013-2017 di Kecamatan Buleleng?. Sesuai dengan rumusan masalah yang dirumuskan maka tujuan dalam penelitian ini yaitu untuk (1) Menganalisis sebaran spasial lokasi rawan kecelakaan lalu lintas selama kurun waktu tahun 2013-2017di Kecamatan Buleleng, (2) Mengidenfitikasi faktor penyebab kecelakaan lalu lintas selama kurun waktu tahun 2013-2017 di Kecamatan Buleleng, (3) Mengkaji tren mortalitas yang terjadi, dilihat dari tingkat kecelakaan lalu lintas selama kurun waktu tahun 2013-2017 di Kecamatan Buleleng. 


\section{Metode}

Penelitian ini adalah penelitian deskriptif. Penelitian deskriptif merupakan penelitian yang gejalanya tidak dibuat oleh peneliti melainkan terjadi secara alamiah. Rancangan penelitian deskriptif ini dimaksudkan untuk mendeskripsikan tren mortalitas berdasarkan tingkat kecelakaan lalu lintas selama kurun waktu tahun 2013 2017 di Kecamatan Buleleng. Data yang dibutuhkan dalam penelitian ini adalah sekunder meliputi (1) Data lokasi kecelakaan lalu lintas berupa data tempat terjadinya kecelakaan lalu lintas di Kecamatan Buleleng selama kurun waktu tahun 2013-2017, berupa arsip laporan kejadian kecelakaan lalu lintas, (2) Data faktor penyebab kecelakaan lalu lintas di Kecamatan Buleleng selama kurun waktu tahun 2013-2017 yang berupa arsip laporan kejadian kecelakaan lalu lintas, (3) Data mortalitas berupa data korban luka fatal (meninggal) selama kurun waktu tahun 2013-2017 di Kecamatan Buleleng yang berupa berupa arsip laporan kejadian kecelakaan lalu lintas.

Metode pengumpulan data yang digunakan yakni pencatatan dokemen dan observasi. Rumusan masalah (1) Dianalis menggunakan teknik analisis deskriptif kualitatif dengan pendekatan keruangan dalam analis pola. Pola dalam hal ini adalah tempat terjadinya kecelakaan yang terpusat atau tersebar di lokasi tertentu. Kemudian akan dideskripsikan dan divisualisasikan dalam bentuk peta sebaran spasial lokasi kecelakaan lalu lintas selama kurun waktu tahun 2013-2017, (2) Dianalis menggunakan teknik analisis deskriptif kualitatif dengan pendekatan lingkungan. Kemudian akan dideskripsikan dan divisualisasikan dalam bentuk tabel, (3) Dianalisis menggunakan teknik analisis deskriptif kualitatif dan menggunakan teknik pengukuran mortalitas yaitu pengukuran angka kematian berdasarkan penyebab (Cause Spesifik Mortality Rate) dan kemudian akan deskripsikan dan divisualisasikan dalam bentuk grafik garis.

\section{Hasil dan Pembahasan}

\subsection{Lokasi Rawan Kecelakaan Lalu Lintas di Kecamatan Buleleng.}

Penentuan lokasi rawan kecelakaan lalu lintas di Kecamatan Buleleng selama kurun waktu tahun 2013-2017 menggunakan tolak ukur dari Departemen Permukiman dan Prasarana Wilayah (2004). Lokasi rawan kecelakaan lalu lintas adalah lokasi tempat sering terjadi kecelakaan lalu lintas dengan tolak ukur tertentu, yaitu ada titik awal dan titik akhir yang meliputi ruas dan simpul jalan yang masingmasing mempunyai jarak panjang atau rasidus tertentu. Ruas jalan di dalam kota ditentukan maksimum 1 (satu) km dengan minimal 2 kecelakaan lalu lintas dengan akibat meninggal dunia atau 5 kecelakaan lalu lintas dengan akibat luka/rugi material (pertahun). Ruas jalan di luar kota ditentukan maksimum 3 (tiga) km dengan minimal 3 kecelakaan lalu lintas dengan akibat meninggal dunia atau 5 kecelakaan lalu lintas dengan akibat luka/rugi material (pertahun). Simpul (persimpangan) dengan radius 100 meter. Adapun hasil penentuan lokasi rawan kecelakaan lalu lintas selama kurun waktu tahun 2013-2017 dapat dilihat pada Tabel 4.8 berikut. 
Tabel 1.

Lokasi Rawan Kecelakaan Lalu Lintas Selama Kurun Waktu Tahun 2013-2017

\begin{tabular}{|c|c|c|c|c|c|c|c|c|c|}
\hline \multirow{2}{*}{ No } & \multirow{2}{*}{ Tahun } & \multirow{2}{*}{ Nama Jalan } & \multirow{2}{*}{ JK } & \multicolumn{6}{|c|}{ Korban } \\
\hline & & & & MD & $\%$ & LB & $\%$ & LR & $\%$ \\
\hline \multirow{2}{*}{1} & \multirow{2}{*}{2013} & $\begin{array}{l}\text { Jln. Singajara - Seririt. Kilometer 10-11. } \\
\text { Desa Kalibubuk }\end{array}$ & 5 & 1 & 12,5 & 0 & 0 & 7 & 87,5 \\
\hline & & $\begin{array}{l}\text { Jln. Setiabudi. Kilometer 3-4. Kelurahan } \\
\text { Penarukan }\end{array}$ & 2 & 2 & 100 & 0 & 0 & 0 & 0 \\
\hline \multirow{6}{*}{2} & \multirow{6}{*}{2014} & $\begin{array}{l}\text { Jln. A. Yani Barat. Kilometer 2-3. } \\
\text { Kelurahan Banyuasri }\end{array}$ & 7 & 1 & 6,25 & 0 & 0 & 15 & 93,76 \\
\hline & & $\begin{array}{l}\text { Jln. Ngurah Rai. Kilometer 0-1. } \\
\text { Kelurahan Banjar Jawa }\end{array}$ & 5 & 1 & 7,69 & 0 & 0 & 12 & 92,30 \\
\hline & & $\begin{array}{l}\text { Jln. Singaraja - Seririt. Kilometer 10-11. } \\
\text { Desa Kalibukbuk }\end{array}$ & 6 & 2 & 25 & 0 & 0 & 6 & 75 \\
\hline & & $\begin{array}{l}\text { Jln. Singaraja - Lovina. Kilometer 5-6. } \\
\text { Desa Pemaron }\end{array}$ & 5 & 0 & 0 & 0 & 0 & 13 & 100 \\
\hline & & $\begin{array}{l}\text { Jln. Singaraja - Seririt. Kilometer 6-7. } \\
\text { Desa Tukadmungga }\end{array}$ & 5 & 1 & 8,33 & 1 & 8,33 & 10 & 83,33 \\
\hline & & $\begin{array}{l}\text { Jln. Surapati. Kilometer 3-4, Kelurahan } \\
\text { Kampung Baru }\end{array}$ & 5 & 1 & $\begin{array}{c}11,1 \\
1\end{array}$ & 0 & 0 & 8 & 88,89 \\
\hline \multirow{2}{*}{3} & \multirow{2}{*}{2015} & $\begin{array}{l}\text { Jln. Viteran. Kilometer 0-1. Kelurahan } \\
\text { Paket Agung }\end{array}$ & 5 & 1 & 10 & 0 & 0 & 9 & 90 \\
\hline & & $\begin{array}{l}\text { Jln. Wr Supratman. Kilometer 4-5. } \\
\text { Kelurahan Penarukan }\end{array}$ & 3 & 2 & 50 & 0 & 0 & 2 & 50 \\
\hline 4 & 2016 & $\begin{array}{l}\text { Jln. Surapati. Kilometer 3-4. Kelurahan } \\
\text { Kampung Baru }\end{array}$ & 5 & 1 & 9,09 & 0 & 0 & 10 & 90,90 \\
\hline \multirow{2}{*}{5} & \multirow{2}{*}{2017} & $\begin{array}{l}\text { Jln. Singaraja - Seritir. Kilometer 10-11. } \\
\text { Desa Kalibukbuk }\end{array}$ & 9 & 4 & $\begin{array}{c}22,2 \\
2\end{array}$ & 0 & 0 & 14 & 77,78 \\
\hline & & $\begin{array}{l}\text { Jln. Wr Supratman. Kilometer 5-6. } \\
\text { Kelurahan Penarukan. }\end{array}$ & 2 & 2 & $\begin{array}{c}66,6 \\
8\end{array}$ & 0 & 0 & 1 & 33,33 \\
\hline
\end{tabular}

Berdasarkan Tabel 1. tentang lokasi rawan kecelakaan lalu lintas selama kurun waktu tahun 2013-2017, dapat dijelaskan bahwa selama kurun waktu tahun 20132017 terdapat 13 titik lokasi rawan kecelakaan lalu lintas di wilayah Kecamatan Buleleng. Lokasi rawan kecelakaan lalu lintas di setiap jalan memiliki tingkat kerawan berbeda yang menyebabkan korban kecelakaan mengalami meninggal dunia, luka berat dan luka ringan. Tingkat kerawan yang menyebabkan korban kecelakaan mengalami meninggal dunia tertinggi terjadi pada tahun 2013 di Jalan Setiabudi, Kilometer 3-4, Kelurahan Penarukan dengan total 100\% korban kecelakaan mengalami meninggal dunia dari 2 kasus kecelakaan lalu lintas. Tingkat kerawan yang menyebabkan korban kecelakaan mengalami luka berat tertinggi terjadi pada tahun 2014 di Jalan Singaraja-Seririt, Kilometer 6-7, Desa Tukadmungga dengan total 8,33\% korban mengalami luka berat dari 5 kasus kecelakaan lalu lintas. Tingkat kerawan yang menyebabkan korban kecelakaan mengalami luka ringan tertinggi terjadi pada 
tahun 2014 di Jalan A. Yani Barat, Kilometer 2-3, Kelurahan Banyuasri dengan total 93,76\% korban mengalami luka ringan dari 7 kasus kecelakaan lalu lintas.

Hasil penentuan lokasi rawan kecelakaan lalu lintas di wilayah Kecamatan Buleleng berdasarkan tolak ukur dari Departemen Permukiman dan Prasarana Wilayah (2004), kemudian divisualisasikan dalam bentuk peta sebaran lokasi rawan kecelakaan lalu lintas yang dapat dilihat pada Gambar 1. 


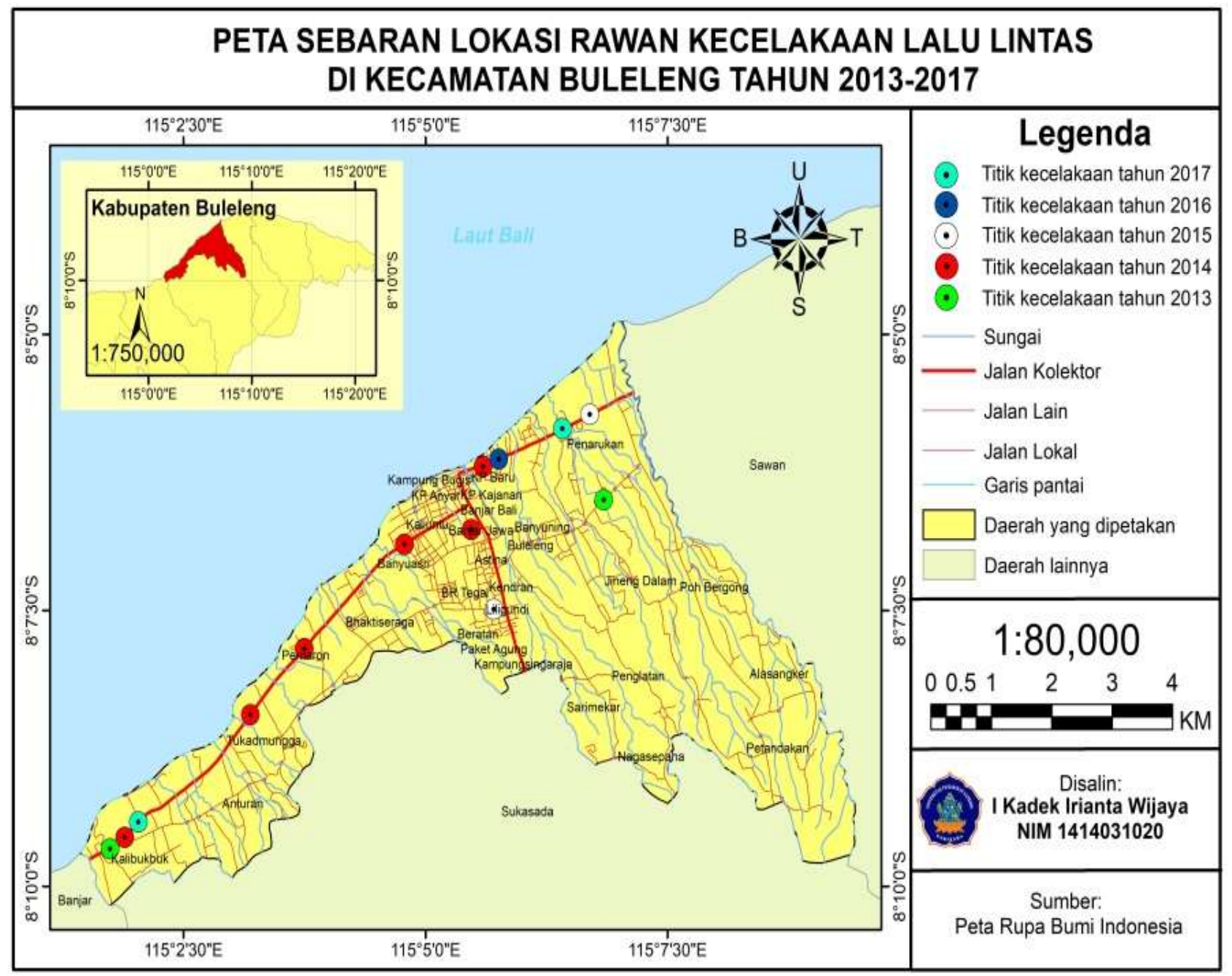

Gambar 1.

Sebaran lokasi rawan kecelakaan lalu lintas selama kurun waktu Tahun 20132017 di Kecamatan Buleleng. 
Berdasarkan Gambar 1. dapat dijelaskan bahwa lokasi rawan kecelakaan lalu lintas di Kecamatan Buleleng selama kurun waktu tahun 2013-2017 memiliki pola yang menyebar disetiap struktur ruang di wilayah Kecamatan Buleleng, yaitu Zona Inti Kota dengan lima (5) lokasi rawan kecelakaan, Zona Selaput Inti Kota dengan lima (3) lokasi rawan kecelakaan dan Zona Pinggiran Kota dengan lima (5) lokasi rawan kecelakaan.

\subsection{Jumlah Kecelakaan berdasarkan Faktor Penyebab selama kurun waktu Tahun 2013-2017.}

Hasil analisis laporan kejadian kecelakaan lalu lintas selama kurun waktu tahun 2013-2017 di Kecamatan Buleleng. Faktor penyebab kecelakaan lalu lintas didominasi oleh faktor manusia. Berikut jumlah kecelakaan berdasarkan faktor penyebab selama kurun waktu tahun 2013-2017 dapat dilihat pada Tabel 2.

Tabel 2.

Jumlah kecelakaan berdasarkan faktor penyebab selama kurun waktu Tahun 2013-

\begin{tabular}{cccccc}
\multicolumn{5}{c}{2017} \\
\cline { 3 - 6 } NO & \multirow{2}{*}{ TAHUN } & JUMLAH & & FAKTOR & \\
\cline { 3 - 6 } & & KECELAKAAN & KENDARAAN & LINGKUNGAN & MANUSIA \\
\hline 1 & 2013 & 146 & 0 & 0 & 146 \\
2 & 2014 & 127 & 0 & 0 & 127 \\
3 & 2015 & 77 & 0 & 0 & 77 \\
4 & 2016 & 111 & 0 & 0 & 111 \\
5 & 2017 & 118 & $\mathbf{0}$ & 0 & 118 \\
\hline \multicolumn{2}{r}{} & JUMLAH & $\mathbf{5 7 9}$ & $\mathbf{0}$ & $\mathbf{5 7 9}$ \\
\hline
\end{tabular}

Sumber : Pengelolaan data sekunder, 2018.

Berdasarkan Tabel 2. dapat dijelaskan bahwa jumlah kecelakaan lalu lintas berdasarkan faktor penyebab didominasi oleh faktor manusia yang mencapai 579 faktor dari total kejadian kecelakaan lalu lintas sebanyak 579 kasus di Kecamatan Buleleng selama kurun waktu tahun 2013-2017. Faktor manusia kemudian di klasifikasikan menjadi dua faktor yaitu faktor manusia akibat tidak berhati-hati dalam bekendara (lengah) dan akibat melanggar peraturan lalu lintas (tidak tertib).

\subsection{Jumlah Korban Meninggal Dunia akibat Kecelakaan Lalu Lintas selama kurun waktu Tahun 2013-2017.}

Hasil analisis laporan kejadian kecelakaan lalu lintas selama kurun waktu tahun 2013-2017 di Kecamatan Buleleng, berdasarkan jumlah korban meninggal dunia akibat kecelakaan lalu lintas mencapai 86 korban jiwa dari total 579 Jumlah Kecelakaan. Adapun jumlah korban meninggal dunia akibat kecelakaan lalu lintas dari tahun 2013-2017 dapat dilihat pada tabel 3. 
Tabel 3.

Jumlah Korban Meninggal Dunia akibat Kecelakaan Lalu Lintas selama kurun waktu Tahun 2013-2017

\begin{tabular}{ccccc}
\hline \multirow{2}{*}{ NO } & TAHUN & JK & \multicolumn{2}{c}{ KORBAN MENINGGAL DUNIA } \\
\cline { 3 - 5 } 1 & 2013 & 146 & $\mathbf{N}$ & $\mathbf{\%}$ \\
2 & 2014 & 127 & 14 & 14,38 \\
3 & 2015 & 77 & 18 & 11,02 \\
4 & 2016 & 111 & 15 & 23,37 \\
5 & 2017 & 118 & 18 & 13,51 \\
\hline
\end{tabular}

Keterangan : (1) JK : Jumlah Kecelakaan (2) MD : Meninggal Dunia

(3) P : Presentase (\%)

Sumber : Pengelolaan data sekunder, 2018.

Berdasarkan Tabel 4.11 dapat dijelaskan bahwa secara absolut jumlah korban meninggal dunia akibat kecelakaan lalu lintas tertinggi terjadi pada tahun 2013 dengan total 21 korban jiwa dari 146 kasus kecelakaan dan terendah terjadi pada tahun 2014 dengan total 14 korban jiwa dari 127 kasus kecelakaan lalu lintas. Namun secara presentasi jumlah korban meninggal dunia akibat kecelakaan lalu lintas tertiggi terjadi pada tahun 2015 dengan presentasi mencapai $23,37 \%$.

Setelah mengetahui total jumlah korban jiwa akibat kecelakaan lalu lintas pertahun selanjutnya dilakukan pengukuran menggunakan angka kematian (cause spesifik mortality rate) untuk mengetahui kemungkinan terjadinya kematian pada penduduk Kecamatan Buleleng akibat kecelakaan lalu lintas yang akan divisualisasikan dalam bentuk grafik tren mortalitas di Kecamatan Buleleng berdasarkan tingkat kecelakaan lalu lintas selama kurun waktu tahun 2013-2017, yang dapat dilihat pada Gambar 2. berikut. 


\section{Tren Mortalitas Berdasarkan Tingkat Kecelakaan Lalu Lintas selama kurun waktu 5 Tahun Terahkir}

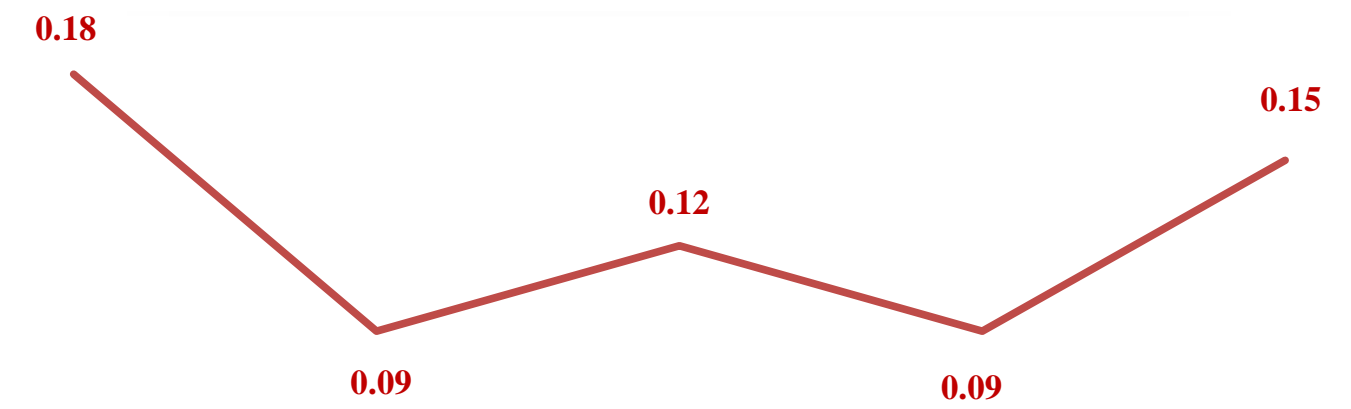

Tahun 2013

Gambar 2.

Grafik tren mortalitas berdasarkan tingkat kecelakaan lalu lintas selama kurun waktu pada tahun 2013 - 2017 di Kecamatan Buleleng

(Sumber: Pengelolaan data sekunder, 2018.)

Berdasarkan Gambar 2. dapat dijelaskan bahwa tren mortalitas di Kecamatan Buleleng berdasarkan tingkat kecelakaan lalu lintas dari tahun 2013-2017 mengalami fluktuaksi. Dibuktikan dengan peningkatan jumlah mortalitas akibat kecelakaan lalu lintas pada tahun 2013, 2015 dan 2017, kemudian mengalami penurunan pada tahun 2014 dan 2016. Secara relatif jumlah mortalitas tertinggi terjadi di tahun 2013 dengan total kemungkinan 0,18 orang per 1.000 penduduk Kecamatan Buleleng mengalami mortalitas akibat kecelakaan lalu lintas dan terendah terjadi di tahun 2014 dan tahun 2016 dengan total kemungkinan 0,09 orang per 1.000 penduduk Kecamatan Buleleng mengalami mortalitas akibat kecelakaan lalu lintas. 


\section{Sebaran Spasial Lokasi Rawan Kecelakaan Lalu Lintas yang terjadi di Kecamatan Buleleng selama kurun waktu tahun 2013 - 2017.}

Lokasi rawan kecelakaan lalu lintas di Kecamatan Buleleng dari tahun 2013 2017 memiliki pola yang menyebar disetiap struktur ruang di wilayah Kecamatan Buleleng, yaitu Zona Inti Kota dengan lima (5) lokasi rawan kecelakaan, Zona Selaput Inti Kota dengan tiga (3) lokasi rawan kecelakaan dan Zona Pinggiran Kota dengan lima (5) lokasi rawan kecelakaan.

Berdasarkan hasil observasi di lokasi kejadian membuktikan bahwa lokasi rawan kecelakaan yang terjadi di Zona Inti Kota diakibatkan oleh faktor manusia. Struktur penggunaan lahan di sekitar lokasi kejadian dominan dipergunakan sebagai pusat pelayan sosial-ekonomi seperti perkantoran, sekolah, pasar dan pertokoan. Selain itu lokasi rawan kecelakaan yang berada di Zona Inti Kota berfungsi sebagai jalan provinsi seperti (1) Jalan A. Yani Barat Kilometer 2-3 Kelurahan Banyuasri menghubungkan Buleleng ke Gilimanuk, (2) Jalan Ngurah Rai Kilometer 0-1 Kelurahan Banjar Jawa menghubungkan Buleleng ke Gilimanuk, (3) Jalan Surapati Kilometer 3-4 Kelurahan Kampung Baru menghubungkan Buleleng ke Amlapura, (4) Jalan Viteran Kilometer 0-1 Kelurahan Penarukan menghubungkan Buleleng ke Denpasar (5) Jalan Surapati Kilometer 3-4 Kelurahan Kampung Baru menghubungkan Buleleng ke Amlapura. Kondisi tersebut menyebabkan arus lalu lintas di lokasi rawan kecelakaan menjadi padat.

Berdasarkan hasil observasi di lokasi kejadian membuktikan bahwa lokasi rawan kecelakaan yang terjadi di Zona Selaput Inti Kota diakibatkan oleh faktor manusia. Struktur penggunaan lahan di sekitar lokasi kejadian dominan dipergunakan sebagai pusat pelayan sosial-ekonomi dengan skala kecil seperti perumahan, kios dan sekolah. Selain itu lokasi rawan kecelakaan yang berada di Zona Selaput Inti Kota berfungsi sebagai jalan kabupaten seperti (1) Jalan Setiabudi kilometer 3-4 Kelurahan Penarukan, (2) Jalan Wr Supratman Kilometer 4-5 Kelurahan Penarukan, (3) Jalan Jalan Wr Supratman Kilometer 5-6 Kelurahan Penarukan. Kondisi tersebut menyebabkan arus lalu lintas di lokasi rawan kecelakaan menjadi bervariatif mengikuti mobilitas penduduk pada jam-jam sibuk ke arah inti kota seperti jam ke kantor, sekolah.

Berdasarkan hasil observasi di lokasi kejadian membuktikan bahwa lokasi rawan kecelakaan yang terjadi di Zona Pinggiran Kota diakibatkan oleh faktor manusia. Struktur penggunaan lahan di sekitar lokasi kejadian dominan dipergunakan sebagai lahan pertanian, namun keberadaan tempat wisata lovina menyebabkan terdapat beberapa pusat pelayan sosial-ekonomi berada di Zona Pinggiran Kota seperti Hotel, Restoran, Pasar dan tempat pelayanan lainnya. Selain itu lokasi rawan kecelakaan yang berada di Zona Pinggiran Kota berfungsi sebagai jalan provinsi seperti (1) Jalan Singaraja-Seririt Kilometer 10-11 Desa Kalibukbuk, (2) Jalan Singaraja-Seririt Kilometer 10-11 Desa Kalibukbuk, (3) Jalan Singaraja-Lovina Kilometer 5-6 Desa Pemaron, (4) Jalan Singaraja-Seririt Kilometer 6-7 Desa Kalibukbuk, (5) Jalan Singaraja-Seririt Kilometer 10-11 Desa Kalibukbuk. Kondisi 
tersebut menyebabkan arus lalu lintas di lokasi rawan kecelakaan menjadi padat dan kendaraan yang berlalu lintas lebih beragam.

Hasil yang sama diungkapkan dalam penelitian Sugiyanto, dkk (2016) yang mengemukakan bahwa karakteristik kecelakaan lalu lintas dan lokasi black spot di Kabupaten Cilacap terjadi di ruas jalan perkotaan dan ruas jalan antar kota. Selain itu faktor penyebab kecelakaan di Kabupaten Cilacap disebabkan oleh faktor manusia dengan presentase $71,69 \%$. Hasil yang sama juga diungkapkan dalam penelitian Susariarta \& Wesnawa (2016) yang mengemukakan bahwa persebaran lokasi kecelakaan lalu lintas tersebar di zona morfologi kota dan mayoritas terjadi di pinggiran Kota Singaraja dengan presentase 43,3\%. Selain itu kecelakaan lalu lintas di Kota Singaraja mayoritas disebabkan oleh faktor kesalahan manusia dengan presentase $98,9 \%$.

\section{Faktor Penyebab Kecelakaan Lalu Lintas yang terjadi di Kecamatan Buleleng selama kurun waktu Tahun 2013-2017.}

Faktor penyebab kecelakaan lalu lintas di Kecamatan Buleleng adalah faktor manusia (pengemudi) yang mencapai 100\% dari total 579 kasus kecelakaan lalu lintas. Hasil yang sama ditunjukan oleh data Direktorat Keselamatan Transportasi Darat (2006), yang mengemukakan bahwa jumlah penyebab kecelakaan lalu lintas di Indonesia paling banyak disebabkan oleh faktor manusia (91\%), faktor kendaraan (5\%), dan faktor jalan sebanyak (3\%) serta faktor lingkungan sebesar (1\%). Faktor manusia sebagai penyebab kecelakaan lalu lintas di Kecamatan Buleleng dari tahun 2013 - 2017 diklasifikasikan menjadi dua faktor yaitu faktor lengah 77,6\% dan faktor melanggar tata tertib 22,5\%. Faktor lengah (kurang berhati-hati) yang dimaksud yaitu pengemudi kendaraan bermotor tidak memperhatikan kondisi arus lalu lintas, tidak menjaga jarak antara kendaraan, tidak memperhatikan pejalan kaki, tidak memberikan pioritas kepada pengemudi lain, saat mendahuli pengemudi mengambil haluan yang berlebih (terlalu ke kanan atau ke kiri) dan faktor tidak tertib (melanggar peraturan lalu lintas) yang dimaksud yaitu pengemudi menerobos traffic light, tidak memberikan pioritas kepada pejalan kaki, berkendara dengan kecepatan tinggi dan melanggar makra jalan. Hasil yang sama diungkapkan dalam penelitian Marsaid, Hidayat, \& Ahsan (2013) yang mengemukakan bahwa faktor lengah mencapai 35,3\% dan tidak tertib 13,3\% dibandingkan faktor-faktor yang lain yang menyebabkan kecelakaan lalu lintas di Kabupaten Malang.

Tren Mortalitas yang terjadi, dilihat dari Tingkat Kecelakaan Lalu Lintas di Kecamatan Buleleng dari Tahun 2013 - 2017.

Hasil penelitian menunjukan bahwa tren mortalitas di Kecamatan Buleleng berdasarkan tingkat kecelakaan lalu lintas dari tahun 2013-2017 mengalami fluktuaksi. Peningkatan jumlah mortalitas akibat kecelakaan lalu lintas terjadi pada tahun 2013, 2015 dan 2017, kemudian mengalami penurunan pada tahun 2014 dan 
2016. Faktor penyebab tinggi-rendahnya mortalitas yang terjadi dari tahun 2013-2017 dipengaruhi oleh jumlah kecelakaan lalu lintas yang terjadi dan tingkat fatalitas korban pada kecelakaan lalu lintas. Pengaruh jumlah kecelakaan lalu lintas terhadap mortalitas yang terjadi dapat dilihat pada tahun 2013, 2014, dan 2017 dan pengaruh tingkat fatalitas yang dialami korban dapat dilihat pada tahun 2015 dan 2016. Hasil yang sama diungkapkan dalam penelitian Rompis. A. dkk, (2016) yang berjudul "Kematian akibat kecelakaan lalu lintas Kota Tomohon tahun 2012-2014" menunjukan bahwa kematian akibat kecelakaan lalu lintas di kota Tomohon 2012-2014 mengalami puncak kenaikan pada tahun 2013. Faktor yang dianggap menentukan tingginya kematian adalah jumlah kecelakaan dan keparahan korban kecelakaan yaitu faktor manusia yang memberikan kontribusi $75-80 \%$ yang juga dipengaruhi oleh faktor kedisiplinan dalam berkendara (80-90\%), faktor kendaraan (4\%), faktor jalan (3\%) , dan faktor lingkungan (1\%).

\section{Simpulan dan Saran}

Berpijak pada hasil temuan dalam pembahasan yang telah dilakukan, dapat disimpulkan tiga hal sesuai dengan rumusan masalah yang telah dikemukakan. Simpulan tersebut dapat dikemukakan sebagai berikut. (1) Sebaran spasial lokasi rawan kecelakaan lalu lintas yang terjadi selama kurun waktu tahun 2013-2017 di Kecamatan Buleleng memiliki memiliki pola yang menyebar disetiap struktur ruang di wilayah Kecamatan Buleleng yaitu di Zona Inti Kota dengan lima lokasi rawan kecelakaan, Pada Zona Selaput Inti Kota dengan lima lokasi rawan kecelakaan, Pada Zona Pinggiran Kota dengan lima lokasi rawan kecelakaan, (2) Faktor penyebab kecelakaan lalu lintas yang terjadi selama kurun waktu tahun 2013-2017 yaitu faktor manusia dengan presentase $100 \%$ dari total jumlah kecelakaan lalu lintas yang mencapai 579 kasus, (3) Tren mortalitas yang terjadi, dilihat dari tingkat kecelakaan lalu lintas selama kurun waktu tahun 2013-2017 mengalami Fluktuasi. Jumlah mortalitas tertinggi terjadi pada tahun 2013 dengan total 21 korban jiwa. Pada tahun 2014 jumlah mortalitas mengalami penurunan menjadi 14 korban jiwa. Pada tahun 2015 jumlah mortalitas kembali mengalami peningkatan menjadi 18 korban jiwa. Pada tahun 2016 jumlah mortalitas kembali mengalami penurunan menjadi 15 korban jiwa. Pada tahun 2017 jumlah mortalias kembali mengalami peningkatan menjadi 18 korban jiwa.

Berdasarkan hasil penelitian yang telah dilakukan, dapat dikemukakan saransaran sebagai berikut (1) Bagi Satuan Lalu Lintas Polres Buleleng Disarankan kepada Satuan Lalu Lintas Polres Buleleng agar meningkatkan kinerja dalam pegembangan Program Dikmas dan Penanganan Korban Kecelakaan Lalu lintas, (2) Bagi Masyarakat Kabupaten Buleleng Disarankan kepada masyarakat Kabupaten Buleleng agar lebih meningkatan kewaspadaan dan kepatuhan terhadap penggunaan fasilitas publik (jalan raya) dan peraturan lalu lintas. 


\section{Ucapan Terimakasih}

Penelitian ini dapat diselesaikan berkat bimbingan dan dukungan dari berbagai pihak. Pada kesempatan ini ucapan terima kasih disampaiakan kepada Rektor Universitas Pendidikan Ganesha, Dekan Fakultas Hukum dan Ilmu Sosial, Ketua Jurusan Pendidikan Geografi, Pembimbing Akademik, Pembimbing 1 dan 2, Penguji 1 dan 2, Staf Dosen Jurusan Pendidikan Geografi, Satuan Lalu Lintas Polres Buleleng dan rekan-rekan mahasiswa Jurusan Pendidikan Geografi angkatan 2014. 


\section{Daftar Rujukan}

Angka Kecelakaan Lalu Lintas Indonesia Termasuk Tinggi di ASEAN. (2017). Retrieved from https://nasional.tempo.co/read/1033993/angka-kecelakaan-lalu-lintasindonesia-termasuk-tinggi-di-asean

Annisak, H., \& M. (2009). "Pertumbuhan Penduduk di Kecamatan Sokobanah Kabupaten Sampang (Studi Multi Situs Laju Pertumbuhan Penduduk di Kecamatan Sokobanah Kabupaten Sampang)." Ekonomi Studi Pembangunan, 2(1), 74-81.

Badan Pusat Statistik. (2017). Kabupaten Buleleng Dalam Angka 2017. Buleleng.

Direktorat Keselamatan Transportasi Darat. Manajemen Keselamatan Transportasi Jalan, Naskah Workshop Manajemen Keselamatan Transportasi Darat, Batam. , (2006).

Djaja, S., Widyastuti, R., Tobing, K., Lasut, D., \& Irianto, J. (2016). Gambaran Kecelakaan Lalu Lintas di Indonesia, Tahun 2010-2014". Ekologi Kesehatan, 15(1), 30-42.

Kementerian Kesehatan Republik Indonesia. (2017). Rata-Rata 3 (tiga) orang meninggal setiap jam akibat Kecelakaan Jalan. Jakarta.

Lembaga Demografi Fakultas Ekonomi Universitas Indonesia. (1981). Dasar-Dasar Demografi. Jakarta: Lembaga Penerbit FEUI.

Marsaid, Hidayat, M., \& Ahsan. (2013). Faktor Yang Berhubungan Dengan Kejadian Kecelakaan Lalu Lintas Pada Pengendara Sepeda Motor Di Wilayah Polres Kabupaten Malang. Jurnal Ilmu Keperawatan, 1(2), 98-112.

Razake, A. A. (1988). Pengantar Kependudukan dan Lingkungan Hidup. Jakarta: P2LPTK.

Siswono, E. (2015). Demografi. Yogyakarta: Penerbit Ombak.

Sugiyanto, G., Mulyono, B., \& Santi, M. Y. (2016). Karakteristik Kecelakaan Lalu Lintas Dan Lokasi Black Spot Di Kab. Cilacap. Jurnal Teknik Sipil, 12(4), 259-266. https://doi.org/10.24002/jts.v12i4.634

Sulistiyowati, N., \& Senewe, F. P. (2014). "Pola Penyebab Kematian Usia Produktif (1554 Tahun) (Analisis Lanjut dari "Pengembangan Registrasi Kematian dan Penyebab Kematian di Kabupaten/Kota di Indonesia Tahun 2012")." Kesehatan Reproduksi, 5(1), 37-47.

Susariarta, I. G., \& Wesnawa, I. G. A. (2016). Analisis Spasial Kecelakaan Lalu Lintas di Kota Singaraja. Jurnal Pendidikan Geografi-Undiksha, 7(1), 96-96. 